\title{
Growth performance, rumen fermentation, nutrient utilization, and metabolic profile of dairy heifers limit-fed distillers dried grains with ad libitum forage
}

\author{
A. K. Manthey ${ }^{1}$ and J. L. Anderson ${ }^{2}$ \\ Dairy and Food Science Department, South Dakota State University, Brookings 57007
}

\begin{abstract}
The objective of this study was to determine the effects of feeding a corn- and soybean-product-based concentrate mix or distillers dried grains with solubles concentrate mix with ad libitum grass hay to dairy heifers. A 16-wk randomized complete block design study was conducted using 24 heifers [18 Holstein and 6 Brown Swiss; $219 \pm 2$ d of age ( \pm standard deviation); $230 \pm 4 \mathrm{~kg}$ of body weight] to evaluate the effect of diet on dry matter intake (DMI), growth performance, rumen fermentation, metabolic profile, and nutrient digestibility. Treatments were (1) corn and soybean product concentrate mix, and (2) distillers-driedgrains-with-solubles-based concentrate mix (DDG). Both concentrate mixes were limit-fed at $0.8 \%$ of body weight and grass hay was offered ad libitum. Heifers were individually fed using Calan gates and orts were recorded daily at feeding. Heifers were weighed every $2 \mathrm{wk}$ and ration concentrate mix offered was adjusted accordingly. Frame measurements and body condition score were recorded every $2 \mathrm{wk}$. Rumen fluid was collected via esophageal tubing during wk 12 and 16 for $\mathrm{pH}$, ammonia N, and volatile fatty acid analysis. Jugular blood samples were collected every 4 wk for metabolite and metabolic hormone analysis. Total-tract digestibility of nutrients was evaluated during wk 16 by fecal grab sampling. No treatment by week interactions were observed for any of the growth measurements and growth measurements and DMI did not differ between treatments. A treatment by time interaction was observed for rumen butyrate percentage with heifers fed DDG having a greater percentage. Total volatile fatty acid concentration, acetate molar percentage, and acetate:propionate decreased with the DDG treatment, whereas propionate molar percentage increased. No treatment by week interactions were observed for any of the metabolites or metabolic hormones measured.
\end{abstract}

Received May 26, 2017.

Accepted August 18, 2017.

${ }^{1}$ Currently with Hubbard Feeds, Mankato, MN 56001.

${ }^{2}$ Corresponding author: jill.anderson@sdstate.edu
A tendency was observed for glucose and plasma urea nitrogen concentration to decrease with DDG. Plasma cholesterol and insulin increased with DDG. Results demonstrated that limit-feeding heifers DDG at $0.8 \%$ of body weight with ad libitum grass hay maintained growth performance, average daily gain, DMI, and gain:feed, with shifts in the metabolic profile compared with the corn and soybean product concentrate mix.

Key words: distillers grains, dairy heifer, growth performance

\section{INTRODUCTION}

Previous research has demonstrated that distillers dried grains with solubles (DDGS) can improve gain: feed and maintain growth performance and ADG when limit-fed or fed ad libitum in a TMR to growing dairy heifers (Schroer et al., 2014; Anderson et al., 2015a; Manthey et al., 2016, 2017). However, relatively little research has focused on limit-feeding a DDGS-based concentrate mix compared with a corn- and soybeanproduct-based concentrate mix with ad libitum grass hay.

Feeding high-fiber feedstuffs to growing dairy heifers may decrease diet digestibility (Zanton and Heinrichs, 2008). Utilizing a limit-feeding strategy, in which nutrient-dense diets are fed to meet but not exceed nutrient requirements, reduces DMI and also has the potential to increase nutrient digestibility while maintaining growth performance (Hoffman et al., 2007; Zanton and Heinrichs, 2009; Anderson et al., 2015a). Anderson et al. (2015a) demonstrated that limit-feeding diets high in DDGS improved $\mathrm{CP}, \mathrm{NDF}$, and ADF digestibility when compared with a corn- and soybean-productbased control concentrate mix; however, the forage was also limit-fed in these diets. That same study also demonstrated DDGS fed as part of a limit-fed ration maintained growth performance of dairy heifers compared with the control diet (Anderson et al., 2015a). In addition, research by Manthey et al. (2016) demonstrated that feeding DDGS at increasing inclusion proportions in limit-fed diets could also maintain heifer growth performance and improve gain:feed. However, 
very limited research is available examining the effects of limit-feeding a corn- and soybean-product-based concentrate mix and DDGS-based concentrate mix with ad libitum forage.

Therefore, the main objective of this study was to determine the effects of limit-feeding a corn- and soybean-product-based concentrate mix compared with DDGS with ab libitum grass hay on DMI, growth performance, rumen fermentation, metabolic profile, and nutrient digestibility. We hypothesized that heifers fed DDGS would have improved gain:feed because of a slightly greater dietary fat concentration, causing the heifers to eat less hay, but growth performance would be maintained.

\section{MATERIALS AND METHODS}

All procedures and animal use were approved before the start of the feeding study by the South Dakota Institutional Animal Care and Use Committee.

\section{Experimental Design}

Twenty-four heifers [18 Holstein and 6 Brown Swiss; $219 \pm 2 \mathrm{~d}$ of age $( \pm \mathrm{SD}) ; 230 \pm 4 \mathrm{~kg}$ of $\mathrm{BW}]$ were used in a randomized complete block design with 2 treatment diets. Heifers were blocked in groups of 2 , based on breed, birth date, and BW. Heifers were randomly assigned to treatment within blocks. Heifers were added to the study based on farm calving rates and were introduced in multiples of 6 with a target start age of 7 mo. Heifers were acclimated to the barns and feeding system for approximately 2 wk followed by an experimental feeding period of $16 \mathrm{wk}$.

Treatment diets (Table 1) were (1) corn and soybean product concentrate mix (CON), and (2) DDGS-based concentrate mix (DDG). Both concentrate mixes were limit-fed at $0.8 \%$ of BW (DM basis) and grass hay was fed ad libitum. Diets were formulated using the NRC (2001) to meet a target ADG of $0.8 \mathrm{~kg} / \mathrm{d}$ when fed to a $250 \mathrm{~kg}$ of BW Holstein heifer and to provide similar protein and energy intakes. The $250 \mathrm{~kg}$ of $\mathrm{BW}$ was a pre-estimated average BW for heifers during the study based on age and herd data. On the last $2 \mathrm{~d}$ of each 2 -wk interval, heifers were weighed. Dry matter analysis of feedstuffs was also performed at this time and amount of concentrate mixes offered was adjusted for the next 2 wk based upon heifer BW and DM analysis of feedstuffs.

To avoid variation in production within plant and over time, DDGS was purchased in one batch and stored at the South Dakota State University Dairy Research and Training Facility. The corn and soybean product concentrate mix was mixed in 0.91-t batches at the South Dakota State University feed mill as needed throughout the feeding period. Hay was purchased in one batch.

\section{Animal Care and Feeding}

This study was conducted at the South Dakota State University Dairy Research and Training Facility (DRTF; Brookings, SD). The study was completed from March 2015 through September 2015 to accommodate available animals and pen space. Heifers were observed daily for health problems and treated according to routine management practices at the DRTF. As part of the routine South Dakota State University DRTF herd management, all Holstein heifers were genomically tested through services provided by Zoetis Inc. (Parsippany, NJ) in cooperation with the Holstein Association USA (Brattleboro, VT). For the testing, hair samples with root balls were collect from heifers within 2 mo of birth. Samples were sent to Zoetis Services Laboratory (Kalamazoo, MI) to be analyzed as part of the Clarifide platform. The DNA was extracted on a $19 \mathrm{~K}$ chip and calculations for PTA and indexes were performed by the Council for Dairy Cattle Breeding (Bowie, MD). Individual heifer data were summarized and provided for download through the Enlight web portal (https:// www.enlightdairy.com).

Heifers were housed in pens of 6 heifers each. Each pen had an inside roofed area $(7 \mathrm{~m} \times 4 \mathrm{~m})$ and an outside dirt exercise lot $(7 \mathrm{~m} \times 23.5 \mathrm{~m})$. The inside areas of the pens were a bedded pack, and were bedded with straw once every 2 wk. Because the consumption of

Table 1. Ingredient composition of treatment diets with limit-fed control or distillers dried grains with solubles (DDG) concentrate mixes with ad libitum grass hay to growing replacement dairy heifers

\begin{tabular}{lcc}
\hline & \multicolumn{2}{c}{ Treatment $^{1}$} \\
\cline { 2 - 3 } Ingredient, \% of DM & Control & DDG \\
\hline Brome grass hay & & \\
DDGS & 68.5 & 68.5 \\
Ground corn & 0.0 & 30.0 \\
Soybean meal & 12.0 & 0.0 \\
Expellers soybean meal & 8.12 & 0.0 \\
Soyhulls & 6.27 & 0.0 \\
Vitamin and mineral premix & 3.65 & 0.0 \\
Calcium carbonate & 0.75 & 0.75 \\
Salt & 0.38 & 0.38 \\
\hline
\end{tabular}

${ }^{1}$ Both treatment diets were formulated with NRC (2001) to contain $13.4 \%$ CP (\% of DM), 7.4\% RDP, $6.0 \%$ RUP, ME of $2.35 \mathrm{Mcal} / \mathrm{kg}$ of $\mathrm{DM}$, and $\mathrm{NE}_{\mathrm{G}}$ of $0.87 \mathrm{Mcal} / \mathrm{kg}$ of DM.

${ }^{2}$ Predicted $\%$ of intake.

${ }^{3}$ Contained: $3.19 \mathrm{~g} / \mathrm{kg}$ of lasalocid, $20.8 \% \mathrm{Ca}, 26.7 \% \mathrm{NaCl}, 1.6 \% \mathrm{Mg}$, $0.5 \% \mathrm{~K}, 880 \mathrm{mg} / \mathrm{kg}$ of $\mathrm{Cu}, 50 \mathrm{mg} / \mathrm{kg}$ of I, $25 \mathrm{mg} / \mathrm{kg}$ of Se, $3,880 \mathrm{mg} / \mathrm{kg}$ of $\mathrm{Zn}, 550,000 \mathrm{IU} / \mathrm{kg}$ of vitamin $\mathrm{A}, 110,000 \mathrm{IU} / \mathrm{kg}$ of vitamin $\mathrm{D}_{3}$, and $4,180 \mathrm{IU} / \mathrm{kg}$ of vitamin $\mathrm{E}$. 
bedding material can be a concern when limit-feeding, pens were only bedded once every 2 wk. Each pen was provided with water ad libitum. Heifers were fed once daily at $0830 \mathrm{~h}$ using the Calan gate feeding system (American Calan Inc., Northwood, NH) and individual intakes were measured. Heifers that had consumed most of their hay during the day were offered additional hay at $1700 \mathrm{~h}$. Bales of hay were coarsely pre-ground with a vertical tub grinder to ease feeding. Diet components were individually weighed for each heifer. The mineral mix was mixed with the concentrate mix before mixing with the grass hay. Orts were weighed and recorded every morning before feeding. Samples of the concentrate mixes and grass hay were taken each week and stored at $-20^{\circ} \mathrm{C}$ until analysis. Ort samples from each group were collected and composited by treatment each week. Individual ingredient samples from the corn and soybean product concentrate mix were taken each time a batch was mixed.

\section{Animal Measurements and Sampling}

Body growth measurements including BW, withers and hip heights, heart and paunch girth, body length, and hip width were measured on 2 consecutive days approximately $4 \mathrm{~h}$ postfeeding at the beginning of the study and then every 2 wk thereafter for the remainder of the study. Body length was measured from the top point of the withers to the end of the ischium (Hoffman, 1997). Body condition score was assessed at the start of the experiment and then every 2 wk thereafter for the remainder of the study by 3 independent observers based on the scale described by Wildman et al. (1982) with $1=$ emaciated and $5=$ obese.

Rumen fluid was sampled from each heifer on 2 consecutive days during wk 12 and 16 at approximately $4 \mathrm{~h}$ postfeeding via esophageal tubing. After discarding the first $200 \mathrm{~mL}$ of fluid to minimize saliva contamination, approximately $50 \mathrm{~mL}$ of rumen fluid was collected. Samples were immediately measured for $\mathrm{pH}$ using a $\mathrm{pH}$ meter (Waterproof pH Testr 30, Oakton Instruments, Vernon Hills, IL) and 2 aliquots $(10 \mathrm{~mL})$ were acidified with either $200 \mu \mathrm{L}$ of $50 \%$ (volume/volume) sulfuric acid or $2 \mathrm{~mL}$ of $25 \%$ (weight/volume) metaphosphoric acid and stored at $-20^{\circ} \mathrm{C}$ until later analyses of $\mathrm{NH}_{3}-\mathrm{N}$ and VFA analysis, respectively.

Blood samples were taken on 2 consecutive days during wk $0,4,8,12$, and 16 of the feeding study for the analysis of cholesterol, glucose, insulin, plasma urea nitrogen, and triglycerides. Blood samples were taken approximately $4 \mathrm{~h}$ postfeeding $(1230 \mathrm{~h})$ via venipuncture of the jugular vein into vacutainer tubes (Becton, Dickinson and Company, Franklin Lakes, NJ) containing sodium fluoride and potassium oxalate for glucose analysis (catalog \#367925) or potassium ethylene diamine tetra-acetic acid $\left(\mathrm{K}_{2} \mathrm{EDTA}\right)$ for all other analyses (catalog \#366643). Following blood collection, samples were immediately placed on ice and brought into the laboratory for processing within $3 \mathrm{~h}$ of collection. Blood collection tubes were centrifuged at 1,000 $\times g$ for 20 min at $4^{\circ} \mathrm{C}$ (Centrifuge CR412, Jouan Inc., Winchester, VA). Plasma ( $\mathrm{K}_{2}$ EDTA tubes) or serum (sodium fluoride and potassium oxalate tubes) was then transferred to polystyrene tubes using a plastic transfer pipette, and frozen at $-20^{\circ} \mathrm{C}$ until further processing and analysis. When samples were analyzed for metabolites or hormones, plasma or serum from the 2 consecutive days during each of the blood sampling weeks (wk 0, 4, 8, 12, and 16) were both analyzed and then averaged for statistical analysis.

For analysis of total-tract digestibility, fecal samples were collected during wk 16 of the feeding period. Acid detergent insoluble ash was used as an internal digestibility marker. Individual heifer orts and fecal grab samples were collected during 3 consecutive days in wk 16 and stored at $-20^{\circ} \mathrm{C}$ until processing and analysis. Fecal sampling time points were scheduled so that the samples represented every $3 \mathrm{~h}$ in a 24 -h feeding cycle.

\section{Laboratory Analysis}

Feed samples were dried for $24 \mathrm{~h}$ at $105^{\circ} \mathrm{C}$ for $\mathrm{DM}$ analysis to adjust dietary ingredient inclusion rates and determine DMI. Samples of the control concentrate, DDGS concentrate mix, and grass hay were collected once weekly and frozen at $-20^{\circ} \mathrm{C}$ until analysis. Samples of the corn and soybean products for the control concentrate mix, DDGS, and grass hay were thawed and samples from 4 consecutive weeks were composited on an as-fed basis by weight. Composite samples were dried in duplicate for $48 \mathrm{~h}$ at $55^{\circ} \mathrm{C}$ in Despatch oven (Style V-23, Despatch Oven Co., Minneapolis, $\mathrm{MN}$ ), ground to $4 \mathrm{~mm}$ particle size with a Wiley Mill (model 3, Arthur H. Thomas Co., Philadelphia, PA), and then further ground to $1 \mathrm{~mm}$ particle size using an ultracentrifuge mill (Brinkman Instruments Co., Westbury, NY). To correct analysis to $100 \%$ DM, 1-g aliquots of feed samples were dried for $4 \mathrm{~h}$ in a $105^{\circ} \mathrm{C}$ oven. Ash content was determined by incinerating $1 \mathrm{~g}$ of sample for $8 \mathrm{~h}$ at $450^{\circ} \mathrm{C}$ in a muffle furnace (AOAC International, 2002, method 942.05). Organic matter was calculated as $\mathrm{OM}=(100-\%$ ash $)$. Samples were analyzed for nitrogen content via Dumas combustion analysis (AOAC International, 2002, method 968.06), on a Rapid N Cube (Elementar Analysensysteme, GmbH, Hanau, Germany). Nitrogen content was then multiplied by 6.25 to calculate CP. Neutral detergent fiber (Van Soest et al., 1991) and ADF (Robertson and 
Van Soest, 1981) were analyzed sequentially using the Ankom 200 fiber analysis system (Ankom Technology Corp., Fairport, NY). For NDF, heat-stable $\alpha$-amylase, and sodium sulfite were used. Petroleum ether was used to determine ether extract (EE; AOAC International, 2002, method 920.39) in an Ankom XT10 fat analysis system (Ankom Technology Corp.). Nonfibrous carbohydrate was calculated as $\% \mathrm{NFC}=100-(\%$ ash $+\%$ $\mathrm{CP}+\% \mathrm{NDF}+\% \mathrm{EE})$ according to the NRC (2001).

Dried and ground samples of the corn and soybean product concentrate mix, DDGS, and grass hay were further composited into 3-mo composites. Group ort samples were also further composited into 4-mo composites. Samples were sent to a commercial laboratory (Dairyland Laboratories Inc., Arcadia, WI) for analysis of minerals $(\mathrm{Ca}, \mathrm{Cl}, \mathrm{Mg}, \mathrm{P}, \mathrm{K}, \mathrm{Na}$, and $\mathrm{S})$ and starch. Mineral content, excluding chloride, was determined using inductively coupled plasma spectroscopy (AOAC International, 1995). Chloride content was determined using a direct reading chloride analyzer (Corning 926, Corning Inc., Corning, NY). Starch was analyzed using a modified procedure analyzing glucose using YSI Biochemistry Analyzer (YSI Inc., Yellow Springs, OH; Bach Knudsen, 1997).

Rumen fluid samples preserved with sulfuric acid were thawed and centrifuged at $30,000 \times g$ for $20 \mathrm{~min}$ at $4^{\circ} \mathrm{C}$ (centrifuge: Eppendorf 5403, Eppendorf North America, Hauppauge, NY) and analyzed for ammonia $\mathrm{N}$ using a colorimetric assay performed on a microplate spectrophotometer (Cary 50, Varian Inc., Walnut Creek, CA) according to Chaney and Marbach (1962). Rumen fluid samples that were preserved with metaphosphoric acid were thawed and centrifuged at 30,000 $\times g$ for $20 \mathrm{~min}$ at $4^{\circ} \mathrm{C}$ and analyzed for acetate, propionate, butyrate, isobutyrate, isovalerate, and valerate concentrations using an automated GC (model 6890, Hewlett-Packard Co., Palo Alto, CA) using a flameionization detector. Volatile fatty acids were separated on a capillary column $(15 \mathrm{~m} \times 0.25 \mathrm{~mm}$ i.d.; Nukol, 17926-01C; Supelco Inc., Bellefonte, PA) using 2-ethylbutyrate as an internal standard. The split ratio of $30: 1$ in the injector port was at a temperature of $250^{\circ} \mathrm{C}$ with flow rate of $1.3 \mathrm{~mL} / \mathrm{min}$ of helium. The column and detector temperature were maintained at 140 and $250^{\circ} \mathrm{C}$, respectively.

Metabolites (cholesterol, glucose, plasma urea nitrogen, and triglycerides) were analyzed with commercially available enzymatic or colorimetric assay kits on a micro-plate spectrophotometer (Cary 50, Varian Inc.). Total plasma cholesterol was analyzed using cholesterol esterase and oxidase (catalog \#C7510, Pointe Scientific Inc., Canton, MI) as described by Allain et al. (1974). Serum glucose was analyzed using glucose oxidase as described by Trinder (1969; catalog \#G7521, Pointe
Scientific Inc.). Plasma urea nitrogen was analyzed using diacetylmonoxime (procedure 0508, Stanbio Laboratory, Boerne, TX). Plasma triglyceride concentration was analyzed using glycerol phosphate oxidase after hydrolysis by lipoprotein lipase as described by Fossati and Prencipe (1982) that paired the reaction with the classic Trinder (1969) reaction.

Insulin was analyzed using a commercially available insulin assay (MP Biomedical) according to the manufacturer's directions. Increasing volumes of bovine serum $(25,50,75$, and $100 \mu \mathrm{L})$ produced a displacement curve that was parallel $(P=0.60)$ to the standard curve (slope $=1.93 \pm 0.22$ for standard curve; slope $=1.77 \pm 0.20$ for bovine serum). Addition of known amounts of insulin (35 and $155 \mu \mathrm{IU} / \mathrm{mL}$ ) to cow serum were accurately recovered (106\%). Interassay and intraassay coefficients of variation were 10.10 and $3.85 \%$, respectively, and assay sensitivity was $5.5 \mu \mathrm{IU} / \mathrm{mL}$.

Fecal samples for each heifer were composited on an as-is basis by volume. Aliquots of $100 \mathrm{~mL}$ of fecal samples were taken from each time point and composited. Orts were collected each day during the collection period. Orts were composited based on proportions of weight from each day. Samples were then dried and ground as previously described for feed samples. Fecal samples were analyzed for DM, ash, CP, NDF, and ADF as previously described for feed samples. Acid detergent insoluble ash analysis was conducted on all feed composites, fecal samples, and orts. The method for acid detergent insoluble ash analysis consists of analyzing the sample for ADF content (Robertson and Van Soest, 1981) and then determining the ash content using a modified procedure of the AOAC 17th ed., method 935.29 (AOAC International, 2002). Digestibility calculations were determined according to Merchen (1988).

\section{Statistical Analysis}

All data were analyzed using SAS version 9.4 (SAS Institute Inc., Cary, NC). The MEANS procedure of SAS was used to estimate the means and standard errors of the nutrients of the monthly feed composites of the individual ingredients and dietary components (i.e., concentrate mix and hay).

Heifer BW, frame measurements, DMI, nutrient intakes, rumen fermentation, and plasma metabolites and hormones were analyzed as a randomized complete block design with week as the repeated measure and the term heifer (block) as the subject using the PROC MIXED procedures of SAS (Littell et al., 2006). The model included treatment, week, breed, as well as treatment $\times$ week, treatment $\times$ breed, and treatment $\times$ breed $\times$ week interactions. Initial body size measure- 
Table 2. Nutrient composition of major ingredients used in the control concentrate mix

\begin{tabular}{lcccc}
\hline $\begin{array}{l}\text { Item, } \\
\text { of DM }\end{array}$ & $\begin{array}{c}\text { Ground } \\
\text { corn }\end{array}$ & $\begin{array}{c}\text { Soybean } \\
\text { meal }\end{array}$ & $\begin{array}{c}\text { Expellers } \\
\text { soybean meal }\end{array}$ & Soyhulls \\
\hline $\mathrm{DM}, \%$ & 84.2 & 88.3 & 89.6 & 89.6 \\
$\mathrm{Ash}$ & 1.30 & 6.47 & 6.50 & 5.16 \\
$\mathrm{OM}$ & 98.7 & 93.5 & 93.5 & 94.8 \\
$\mathrm{CP}$ & 8.17 & 52.4 & 47.8 & 43.4 \\
$\mathrm{ADF}$ & 2.59 & 4.78 & 22.75 & 63.0 \\
$\mathrm{NDF}$ & 9.33 & 8.41 & 7.25 & 1.01 \\
$\mathrm{EE}$ & 3.09 & 68.85 & 84.3 & \\
$\mathrm{NFC}^{3}$ & 21.9 & & \\
${ }^{1} \%$ of DM, unless otherwise indicated. & & \\
${ }^{2} \mathrm{Results}$ from analysis of 3-batch composites $(\mathrm{n}=1)$. & \\
${ }^{3} \mathrm{EE}=$ ether extract. & &
\end{tabular}

ments, BW, and metabolite concentrations were included as covariates within the model. The slice option was used to determine $P$-values for differences between treatment at individual weeks or more specifically at the wh 16 or final time point. Akaike's criterion was used to determine the most suitable covariance structure in repeated measures for each variable. Covariance structures tested were compound symmetry, first-order autoregressive, Toeplitz, and unstructured. Compound symmetry resulted in the least absolute Akaike's values and was used for the final model. Significant differences among treatments were declared at $P \leq 0.05$ and tendencies were declared at $0.05<P \leq 0.10$.

Regression procedures of SAS were used to determine average change per day for ADG and body frame measurements. The $P$-values for the interaction of treatment and time using MIXED analysis were used to determine significance of change per day among treatments (Kutner et al., 2004). Gain-to-feed ratio was calculated as the ratio of $\mathrm{ADG}$ (slope of $\mathrm{BW}$ regression) to DMI for each treatment. For comparison of analyses, ADG and gain:feed ratios were also calculated based on 2-wk interval data and analyzed using MIXED procedures with repeated measures similar to frame size measurements.

The MIXED procedures of SAS were used for the analysis of total-tract digestibility of nutrients. The model included treatment with block included as a random variable because samples were analyzed from a single time period in wk 16 of the study.

\section{RESULTS AND DISCUSSION}

\section{Feed Analysis}

The nutrient composition of the individual ingredients used in the corn and soybean product concentrate mix is presented in Table 2. Values are comparable to those listed in the NRC (2001) for the same feedstuffs.
Nutrient composition of the CON and DDG mixes, as well as the grass hay, is presented in Table 3 . Note that as DDGS was the only ingredient in the DDG concentrate mix (as a mineral and vitamin mix was added at time of feeding), its nutrient composition is presented in Table 3. Because the DDGS was purchased in one batch at the beginning of the study, little variation was present in the nutrient composition over the duration of the study; however, some variation was present in the nutrient composition of the grass hay. Nutrient composition of the CON mix also varied very little.

Average nutrient composition of the experimental diets over the duration of the study is presented in Table 4. The nutrient composition was calculated based upon average intake of concentrate and grass hay nutrients and the nutrient composition of the monthly composites by group of ort samples for each treatment. Average EE, NDF, and ADF composition were greater for the DDG diet, whereas NFC and starch were decreased in the DDG diet. Because heifers were limit-fed the concentrate mix and given grass hay ad libitum, there was some variation in the nutrient composition of the rations over time; however, rations were providing adequate nutrients to the heifers and are comparable to those typically fed to growing dairy heifers.

Differences in the nutrient composition of the rations were related to the nutrient intakes (Table 5). Neutral detergent fiber intake tended to increase and EE increased with DDGS due to the increased concentration of NDF and EE in the DDG concentrate mix compared with the CON. Starch and NFC intake decreased with the DDG concentrate mix due to decreased concentrations of these nutrients in the DDG concentrate mix.

\section{Heifer Performance}

Body weight, DMI, and gain:feed results are presented in Table 6. No interactions were observed of 
Table 3. Nutrient composition of the control concentrate mix and distillers dried grains with solubles (DDG) and forage

\begin{tabular}{|c|c|c|c|c|c|c|}
\hline \multirow{3}{*}{$\begin{array}{l}\text { Item, }{ }^{1,2} \% \\
\text { of DM }\end{array}$} & \multicolumn{4}{|c|}{ Concentrate mix } & \multirow{2}{*}{\multicolumn{2}{|c|}{$\frac{\text { Forage }}{\text { Grass hay }}$}} \\
\hline & \multicolumn{2}{|c|}{ Control } & \multicolumn{2}{|c|}{ DDG } & & \\
\hline & Mean & $\mathrm{SE}$ & Mean & SE & Mean & $\mathrm{SE}$ \\
\hline$\overline{\mathrm{DM}}{ }^{3} \%$ & 86.7 & 0.13 & 88.4 & 0.31 & 88.5 & 0.40 \\
\hline $\mathrm{Ash}^{3}$ & 4.30 & 0.02 & 5.15 & 0.06 & 9.05 & 0.18 \\
\hline $\mathrm{OM}^{3}$ & 95.7 & 0.02 & 94.9 & 0.06 & 91.0 & 0.18 \\
\hline $\mathrm{CP}^{3}$ & 29.5 & 0.15 & 30.6 & 0.08 & 6.68 & 0.12 \\
\hline $\mathrm{ADF}^{3}$ & 10.0 & 0.18 & 11.9 & 0.15 & 37.3 & 0.77 \\
\hline $\mathrm{NDF}^{3}$ & 19.2 & 0.25 & 34.8 & 0.25 & 65.2 & 0.90 \\
\hline $\mathrm{EE}^{3}$ & 2.97 & 0.11 & 10.2 & 0.09 & 1.54 & 0.14 \\
\hline $\mathrm{NFC}^{3,4}$ & 44.0 & 0.26 & 19.2 & 0.28 & 17.6 & 0.84 \\
\hline Starch $^{5}$ & 29.3 & 0.19 & 4.27 & 0.13 & 0.38 & 0.040 \\
\hline $\mathrm{Ca}^{5}$ & 0.28 & 0.010 & 0.11 & 0.000 & 0.35 & 0.020 \\
\hline $\mathrm{P}^{5}$ & 0.48 & 0.010 & 0.94 & 0.010 & 0.23 & 0.005 \\
\hline $\mathrm{Mg}^{5}$ & 0.26 & 0.005 & 0.35 & 0.005 & 0.20 & 0.005 \\
\hline $\mathrm{K}^{5}$ & 1.61 & 0.040 & 1.20 & 0.005 & 2.04 & 0.070 \\
\hline$S^{5}$ & 0.27 & 0.000 & 0.73 & 0.005 & 0.15 & 0.01 \\
\hline $\mathrm{Na}^{5}$ & 0.01 & 0.000 & 0.26 & 0.010 & 0.01 & 0.000 \\
\hline $\mathrm{Cl}^{5}$ & 0.08 & 0.005 & 0.20 & 0.010 & 0.75 & 0.040 \\
\hline
\end{tabular}

${ }_{1} \%$ of DM, unless otherwise indicated.

${ }^{2}$ Does not include vitamin and mineral premix, calcium carbonate, or salt because a mixture of these was added and mixed into the rations at feeding time.

${ }^{3}$ Results from analysis of monthly composites $(n=6)$.

${ }^{4} \% \mathrm{NFC}=100-(\%$ ash $+\% \mathrm{CP}+\% \mathrm{NDF}+\% \mathrm{EE})(\mathrm{NRC}, 2001) . \mathrm{EE}=$ ether extract

${ }^{5}$ Results from analysis of 3 -mo composites $(\mathrm{n}=2)$.

treatment by week for any of the variables measured. Also, no differences were observed in BW, ADG, or gain:feed. However, the ADG in this experiment was greater than the target recommendation of $0.8 \mathrm{~kg} / \mathrm{d}$
(Zanton and Heinrichs, 2005). This experiment, as well as Anderson et al. (2015a) and Manthey et al. (2016), suggest that the NRC (2001) overestimates the energy requirements of growing dairy heifers or underestimates

Table 4. Mean ration composition based on intakes for heifers limit-fed a control or distillers dried grains with solubles (DDG) concentrate mix with ad libitum grass hay

\begin{tabular}{|c|c|c|c|c|c|c|}
\hline \multirow{2}{*}{$\begin{array}{l}\text { Nutrient, \% } \\
\text { of DM }\end{array}$} & \multicolumn{2}{|c|}{ Treatment } & \multirow[b]{2}{*}{ SEM } & \multicolumn{3}{|c|}{$P$-value ${ }^{1}$} \\
\hline & Control & DDG & & Trt & Wk & Trt $\times W k$ \\
\hline$\overline{\mathrm{DM}^{2}}$ & 89.2 & 89.8 & 0.10 & $<0.01$ & $<0.01$ & 0.92 \\
\hline $\mathrm{Ash}^{2}$ & 9.55 & 9.75 & 0.091 & 0.15 & $<0.01$ & 0.45 \\
\hline $\mathrm{CP}^{2}$ & 15.6 & 15.0 & 0.40 & 0.26 & $<0.01$ & 0.96 \\
\hline $\mathrm{NDF}^{2}$ & 55.6 & 62.4 & 0.80 & $<0.01$ & $<0.01$ & 0.58 \\
\hline $\mathrm{ADF}^{2}$ & 31.5 & 33.1 & 0.53 & 0.04 & $<0.01$ & 0.88 \\
\hline $\mathrm{EE}^{2,3}$ & 2.21 & 4.45 & 0.095 & $<0.01$ & $<0.01$ & $<0.01$ \\
\hline $\mathrm{NFC}^{2}$ & 29.2 & 19.9 & 0.40 & $<0.01$ & $<0.01$ & $<0.01$ \\
\hline $\operatorname{Starch}^{4}$ & 10.8 & 1.63 & 0.42 & $<0.01$ & $<0.01$ & $<0.01$ \\
\hline $\mathrm{Ca}^{4}$ & 0.60 & 0.51 & 0.020 & $<0.01$ & $<0.01$ & 0.68 \\
\hline $\mathrm{P}^{4}$ & 0.34 & 0.48 & 0.008 & $<0.01$ & $<0.01$ & $<0.01$ \\
\hline $\mathrm{Mg}^{4}$ & 0.24 & 0.27 & 0.002 & $<0.01$ & $<0.01$ & 0.05 \\
\hline $\mathrm{K}^{4}$ & 2.15 & 2.01 & 0.012 & $<0.01$ & $<0.01$ & 0.56 \\
\hline$S^{4}$ & 0.21 & 0.34 & 0.005 & $<0.01$ & $<0.01$ & $<0.01$ \\
\hline $\mathrm{Na}^{4}$ & 0.25 & 0.29 & 0.008 & $<0.01$ & $<0.01$ & 0.60 \\
\hline $\mathrm{Cl}^{4}$ & 0.91 & 0.91 & 0.013 & 0.85 & $<0.01$ & 0.52 \\
\hline
\end{tabular}

${ }^{1}$ Significance of effects for treatment (Trt), week $(\mathrm{Wk})$, and treatment $\times$ week $($ Trt $\times \mathrm{Wk})$.

${ }^{2}$ Results from analysis of monthly composites $(\mathrm{n}=6)$.

${ }^{3} \mathrm{EE}=$ ether extract.

${ }^{4}$ Results from analysis of 3 -mo composites $(n=2)$. 
Table 5. Mean nutrient intake amounts for heifers limit-fed a control or distillers dried grains with solubles (DDG) concentrate mix with ad libitum grass hay

\begin{tabular}{|c|c|c|c|c|c|c|}
\hline \multirow{2}{*}{$\begin{array}{l}\text { Nutrient, } \\
\mathrm{kg} / \mathrm{d}\end{array}$} & \multicolumn{2}{|c|}{ Treatment } & \multirow[b]{2}{*}{ SEM } & \multicolumn{3}{|c|}{$P$-value ${ }^{1}$} \\
\hline & Control & DDG & & Trt & $\mathrm{Wk}$ & $\operatorname{Trt} \times \mathrm{Wk}$ \\
\hline$\overline{\mathrm{DM}^{2}}$ & 6.40 & 6.62 & 0.266 & 0.57 & $<0.01$ & 0.63 \\
\hline Ash & 0.62 & 0.65 & 0.028 & 0.42 & $<0.01$ & 0.61 \\
\hline $\mathrm{CP}^{2}$ & 0.97 & 0.97 & 0.027 & 0.94 & $<0.01$ & 0.65 \\
\hline $\mathrm{NDF}^{2}$ & 3.62 & 4.15 & 0.199 & 0.07 & $<0.01$ & 0.47 \\
\hline $\mathrm{ADF}^{2}$ & 2.04 & 2.21 & 0.114 & 0.33 & $<0.01$ & 0.59 \\
\hline $\mathrm{EE}^{2,3}$ & 0.14 & 0.29 & 0.007 & $<0.01$ & $<0.01$ & $<0.01$ \\
\hline $\mathrm{NFC}^{2}$ & 1.85 & 1.33 & 0.052 & $<0.01$ & $<0.01$ & 0.49 \\
\hline Starch $^{4}$ & 0.66 & 0.10 & 0.014 & $<0.01$ & $<0.01$ & $<0.01$ \\
\hline $\mathrm{Ca}^{4}$ & 0.039 & 0.034 & 0.0016 & 0.07 & $<0.01$ & 0.87 \\
\hline $\mathrm{P}^{4}$ & 0.021 & 0.031 & 0.0009 & $<0.01$ & $<0.01$ & $<0.01$ \\
\hline $\mathrm{Mg}^{4}$ & 0.016 & 0.018 & 0.0006 & 0.03 & $<0.01$ & 0.44 \\
\hline $\mathrm{K}^{4}$ & 0.14 & 0.13 & 0.006 & 0.68 & $<0.01$ & 0.73 \\
\hline $\mathrm{S}^{4}$ & 0.013 & 0.022 & 0.0006 & $<0.01$ & $<0.01$ & $<0.01$ \\
\hline $\mathrm{Na}^{4}$ & 0.015 & 0.018 & 0.0004 & $<0.01$ & $<0.01$ & $<0.01$ \\
\hline $\mathrm{Cl}^{4}$ & 0.058 & 0.060 & 0.0026 & 0.54 & $<0.01$ & 0.62 \\
\hline
\end{tabular}

${ }^{1}$ Significance of effects for treatment (Trt), week $(\mathrm{Wk})$, and treatment $\times$ week $($ Trt $\times \mathrm{Wk})$.

${ }^{2}$ Results from analysis of monthly composites $(\mathrm{n}=6)$.

${ }^{3} \mathrm{EE}=$ ether extract, petroleum.

${ }^{4}$ Results from analysis of 3 -mo composites $(\mathrm{n}=2)$.

the energy provided by ingredients. Dry matter intake was expected to decrease and gain:feed was expected to be improved with the DDG diet; however, this was not observed.

Frame measurements are presented in Table 7. Based on genomic data, Holstein heifers had similar PTA for type composite score (1.49 and 1.57 for CON and DDG, respectively, $\mathrm{SEM}=0.154, P=0.72$ ); as a result, it was not used as a covariate term for growth performance. No treatment by week interactions were observed for any of the growth variables measured. Frame measurements increased over time, but were not different among treatments. Also, no difference was observed in change per day for any of the frame measurements, suggesting that heifers were consuming adequate nutrients to promote growth throughout the experimental period. There was also no difference in BCS (Table 7). These results are consistent with those found by Anderson et al. (2015a) and Manthey et al. (2016) who limit-fed TMR containing DDGS to growing dairy heifers.

Table 6. Dry matter intake, BW, and gain-to-feed ratios for heifers limit-fed a control or distillers dried grains with solubles (DDG) concentrate mix with ad libitum grass hay

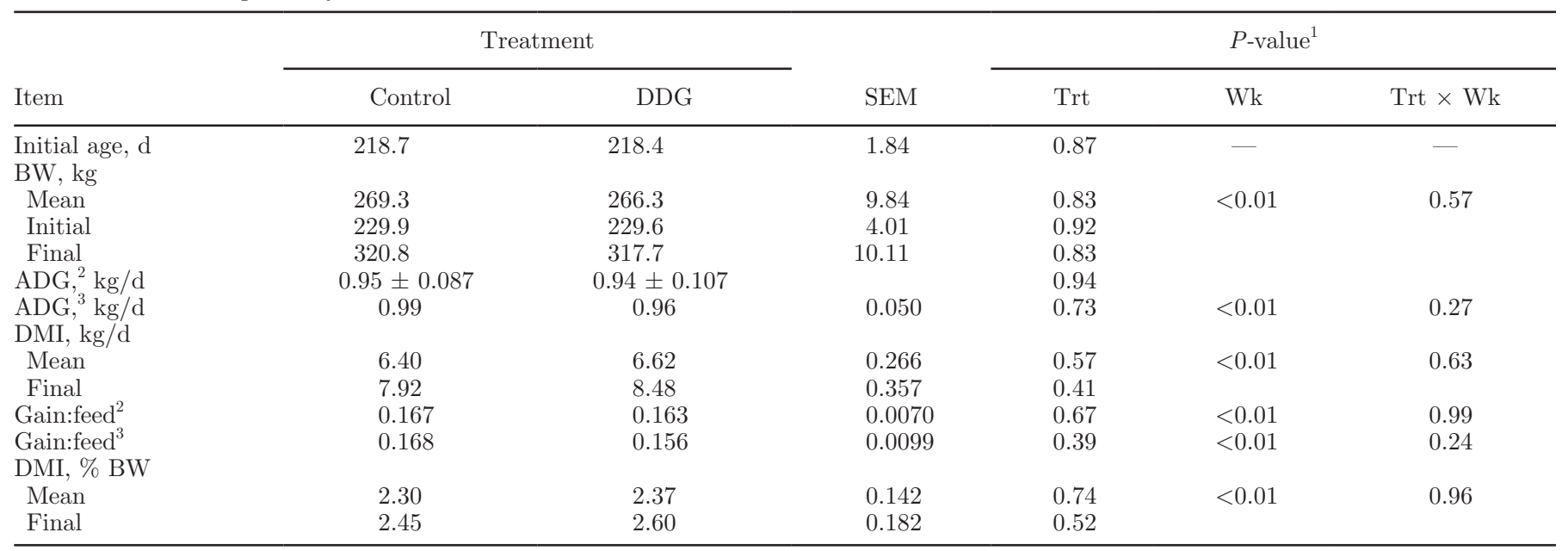

${ }^{1}$ Significance of effects for treatment (Trt), week $(\mathrm{Wk})$, and treatment $\times$ week $($ Trt $\times \mathrm{Wk})$.

${ }^{2}$ Calculated using regression analysis of BW of the day of the study.

${ }^{3}$ Calculated based on change per 2-wk intervals. 
Table 7. Frame size measurements for heifers limit-fed a control or distillers dried grains with solubles (DDG) concentrate mix with ad libitum grass hay

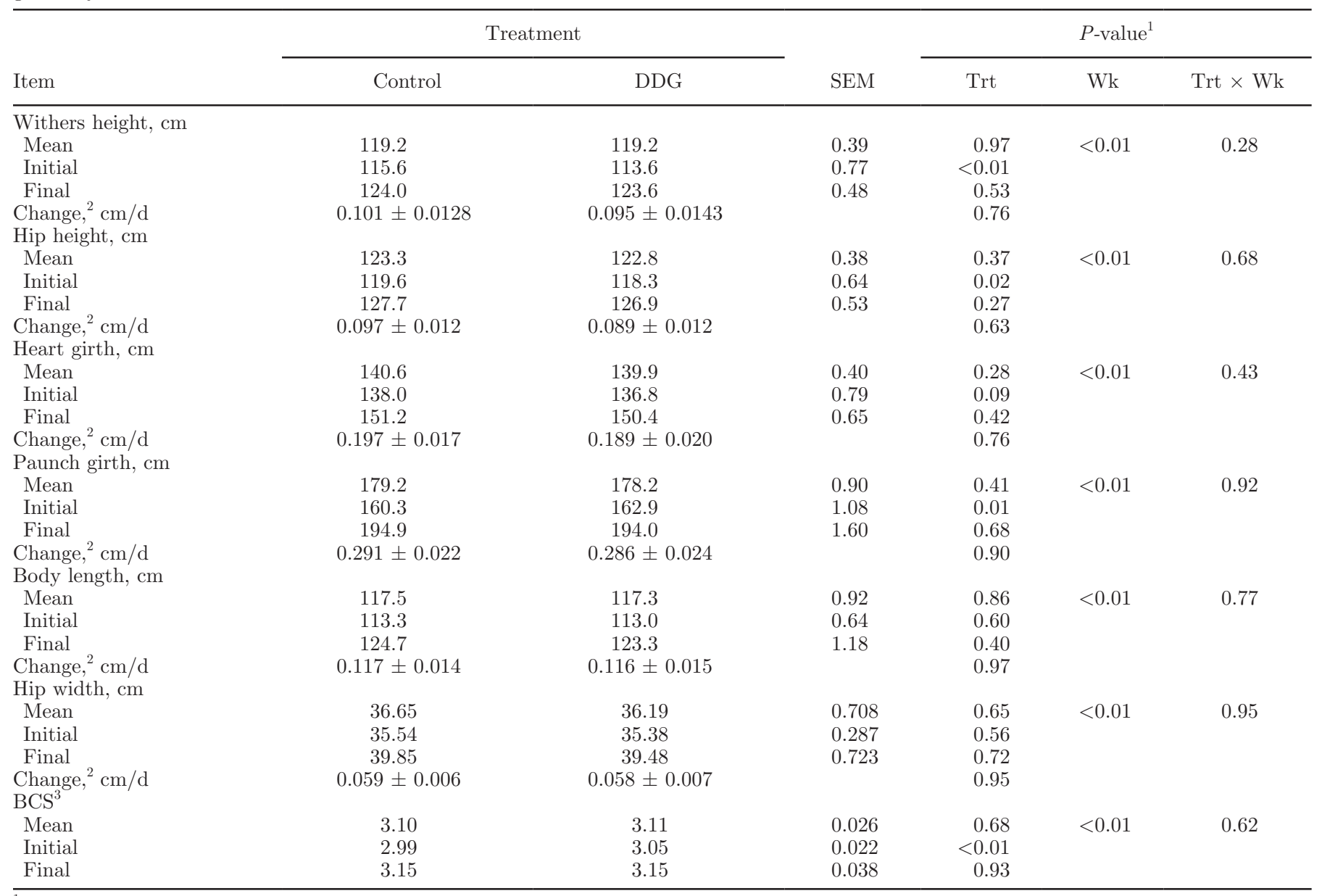

${ }^{1}$ Significance of effects for treatment (Trt), week $(\mathrm{Wk})$, and treatment $\times$ week (Trt $\left.\times \mathrm{Wk}\right)$.

${ }^{2}$ Calculated using regression analysis of BW of the day of the study.

${ }^{3}$ Body condition score with $1=$ emaciated and $5=$ obese (Wildman et al., 1982).

\section{Rumen Fermentation}

Rumen fermentation characteristics are presented in Table 8. Collecting rumen fluid samples via esophageal tube is not an ideal method and results should be regarded with caution; however, our objective for collection these samples was mainly to determine if any treatment effects were present on the relative proportions of VFA. A tendency was observed for a treatment by week interaction for butyrate molar percentage. Acetate percentage, total VFA concentration, and acetate: propionate decreased, whereas propionate percentage increased with the DDG diet compared with the CON diet. The shift in molar VFA concentrations is most likely the result of the difference in starch concentration between the concentrate mixes. This may have also led to the decrease in acetate percentage and increase in propionate molar percentage in the DDG diet. This suggests that heifers fed the DDG diet had more efficient rumen fermentation as demonstrated by greater propionate molar percentage because there is less methane and carbon dioxide production in propionate as compared with acetate (Fahey and Berger, 1988). However, this shift in rumen fermentation did not result in differences in DMI, gain:feed, or overall growth performance in the DDG diet.

\section{Metabolites and Metabolic Hormones}

Average metabolite and metabolic hormone concentrations are presented in Table 9. No treatment by week interactions were present for any of the metabolites or metabolic hormones measured. No differences were observed in concentrations of plasma triglycerides, which are the storage form of fat within the body. This is consistent with results reported by Manthey et al. (2017) 
Table 8. Rumen fermentation parameters of heifers limit-fed a control or distillers dried grains with solubles (DDG) concentrate mix with ad libitum grass hay

\begin{tabular}{|c|c|c|c|c|c|c|}
\hline \multirow[b]{2}{*}{ Item } & \multicolumn{2}{|c|}{ Treatment } & \multirow[b]{2}{*}{ SEM } & \multicolumn{3}{|c|}{$P$-value ${ }^{1}$} \\
\hline & Control & DDG & & Trt & $\mathrm{Wk}$ & Trt $\times W k$ \\
\hline $\mathrm{pH}$ & 6.86 & 6.93 & 0.082 & 0.57 & 0.53 & 0.78 \\
\hline $\mathrm{NH}_{3}-\mathrm{N}, \mathrm{mg} / \mathrm{dL}$ & 8.70 & 9.40 & 0.697 & 0.48 & 0.18 & 0.99 \\
\hline Total VFA, $\mathrm{m} M$ & 78.5 & 69.8 & 2.40 & $<0.01$ & 0.26 & 0.91 \\
\hline Acetate, $\mathrm{mmol} / 100 \mathrm{mmol}$ & 69.3 & 65.2 & 0.39 & $<0.01$ & 1.00 & 0.65 \\
\hline Propionate, $\mathrm{mmol} / 100 \mathrm{mmol}$ & 21.2 & 23.6 & 0.23 & $<0.01$ & 0.41 & 0.30 \\
\hline Isobutyrate, $\mathrm{mmol} / 100 \mathrm{mmol}$ & 0.09 & 0.16 & 0.062 & 0.46 & 0.91 & 0.29 \\
\hline Butyrate, $\mathrm{mmol} / 100 \mathrm{mmol}$ & 8.23 & 9.62 & 0.251 & $<0.01$ & 0.57 & 0.06 \\
\hline Isovalerate, $\mathrm{mmol} / 100 \mathrm{mmol}$ & 0.62 & 0.54 & 0.044 & 0.19 & 0.01 & 0.51 \\
\hline Valerate, $\mathrm{mmol} / 100 \mathrm{mmol}$ & 0.56 & 0.87 & 0.031 & $<0.01$ & 0.23 & 0.70 \\
\hline Acetate:propionate & 3.28 & 2.78 & 0.048 & $<0.01$ & 0.53 & 0.42 \\
\hline
\end{tabular}

${ }^{1}$ Significance of effects for treatment (Trt), week $(\mathrm{Wk})$, and treatment $\times$ week $($ Trt $\times$ Wk).

in which no differences were observed in concentrations of plasma triglycerides when heifers were fed increasing concentrations of DDGS in replacement of forage. However, Park et al. (1983) found that increasing the dietary fat by increasing the inclusion rate of sunflower seeds led to an increase in the concentration of plasma triglycerides. An increase occurred in the concentration of plasma cholesterol with the DDG diet compared with the CON diet. This is speculated to be a result of the increased dietary fat from the DDGS in the DDG diet. Anderson et al. (2015b) limit-fed dairy heifers a corn- and soybean-product-based concentrate diet, lowfat DDGS, and high-fat DDGS diet and found that heifers fed the high-fat DDGS had greater concentrations of plasma cholesterol. Other researchers have also reported increased concentrations of plasma cholesterol with increased dietary concentrations of dietary fat (Park et al., 1983; Talavera et al., 1985; Thomas et al., 1997; Funston, 2004). Previous research has reported an inverse relationship between dietary $\mathrm{CP}$ and cholesterol suggesting that $\mathrm{CP}$ is required for the synthesis of cholesterol or that a protein deficiency hastens cholesterol synthesis (Park et al., 1980). However, this cannot explain the results in the current experiment.
A tendency was observed for the concentration of serum glucose to decrease with the DDG diet compared with the CON diet. Anderson et al. (2015c) had similar results, reporting that heifers fed a high-fat DDGS diet had decreased concentrations of serum glucose when compared with the corn and soybean product control diet. However, the forage was not offered ad libitum in that study. This decrease in serum glucose in the current study may be attributed to the increased dietary fat and reduced starch in the DDG diet (Park et al., 1980). Concentrations of blood glucose have been shown to decrease as heifers were fed diets with elevated fat concentrations (Park et al., 1980). It was speculated that the changes in rumen fermentation with increased dietary fat decreased glucogenic nutrient availability and decreased propionate production, which is glucogenic (Park et al., 1980). However, the propionate molar percentage was greater for the DDG diet in the current study. A tendency was observed for a decrease in the concentration of plasma urea nitrogen in the DDG compared with the CON diet. This may be the result of the differences in digestibility of the $\mathrm{CP}$ between the CON grain mix, which contained soybean products and the DDGS that was fed. Kleinschmit et

Table 9. Plasma metabolites and metabolic hormone concentrations for heifers limit-fed a control or distillers dried grains with solubles (DDG) concentrate mix with ad libitum grass hay

\begin{tabular}{|c|c|c|c|c|c|c|}
\hline \multirow[b]{2}{*}{ Item } & \multicolumn{2}{|c|}{ Treatment } & \multirow[b]{2}{*}{ SEM } & \multicolumn{3}{|c|}{$P$-value ${ }^{1}$} \\
\hline & Control & DDG & & Trt & Wk & Trt $\times W k$ \\
\hline Cholesterol, mg/dL & 81.14 & 102.2 & 3.88 & $<0.01$ & 0.20 & 0.45 \\
\hline Glucose ${ }^{2} \mathrm{mg} / \mathrm{dL}$ & 75.24 & 71.72 & 1.28 & 0.07 & $<0.01$ & 0.81 \\
\hline Insulin, $\mathrm{ng} / \mathrm{mL}$ & 0.55 & 0.70 & 0.041 & 0.01 & $<0.01$ & 0.15 \\
\hline Plasma urea $\mathrm{N}, \mathrm{mg} / \mathrm{dL}$ & 12.49 & 11.59 & 0.31 & 0.06 & 0.49 & 0.64 \\
\hline Triglycerides, mg/dL & 19.64 & 20.95 & 0.95 & 0.34 & 1.00 & 0.97 \\
\hline
\end{tabular}

${ }^{1}$ Significance of effects for treatment (Trt), week $(\mathrm{Wk})$, and treatment $\times$ week $($ Trt $\times$ Wk).

${ }^{2}$ Glucose was measured from serum samples instead of plasma. 
al. (2007) found that the CP in soybean meal was more degradable within the rumen, whereas DDGS contains more RUP that undergoes intestinal digestion. The differences in the concentration of plasma urea nitrogen are inconsistent with Anderson et al. (2015b) who found no differences between the control and high-fat DDGS diets.

Concentration of plasma insulin increased in the DDG compared with the CON diet. Previous research has indicated that concentration of serum insulin increased in heifers fed ad libitum compared with limit-fed (Sejrsen et al., 1983). However, in the current study, heifers were fed grass hay ad libitum and had lower concentrations of plasma insulin compared with heifers from previous experiments in which limit-feeding strategies were used (Anderson et al., 2015b; Manthey et al., 2017). The differences in the current study may be attributed to the tendency for differences in concentration of serum glucose, but more research is warranted.

\section{Apparent Total-Tract Nutrient Digestion}

Apparent total-tract nutrient digestibility is presented in Table 10. No differences were observed in digestibility between treatments for any of the nutrients measured. This is inconsistent with findings by Anderson et al. (2015a) who reported an increase in the digestibility of $\mathrm{CP}$ and fiber when diets were fed with full-fat DDGS compared with low-fat DDGS diets and a control diet. The nutrient digestibility for both treatments in the current experiment is also less than that reported in research that had limit-fed diets containing DDGS (Anderson et al., 2015a; Manthey et al., 2016). Feeding grass hay ad libitum in the current study may explain these overall digestibility differences compared with results from research with limit-fed diets. Diets that are limit-fed typically result in increased nutrient digestibility due to changes in feed passage rate through the gastrointestinal tract and differences in gut fill (Zanton and Heinrichs, 2007).

Table 10. Total-tract digestibility of nutrients for heifers limit-fed a control or distillers dried grains with solubles (DDG) concentrate mix with ad libitum grass hay

\begin{tabular}{lccrc}
\hline & \multicolumn{2}{c}{ Treatment } & & $P$-value \\
\cline { 2 - 3 } \cline { 5 - 5 } Item, \% & Control & DDG & SEM & Treatment \\
\hline DM & 60.4 & 57.6 & 2.78 & 0.22 \\
OM & 62.9 & 60.1 & 2.58 & 0.19 \\
CP & 60.5 & 55.4 & 5.45 & 0.20 \\
NDF & 56.5 & 58.2 & 2.86 & 0.43 \\
ADF & 51.0 & 52.5 & 2.38 & 0.44 \\
\hline
\end{tabular}

${ }^{1}$ Significance of effects for treatment.

\section{CONCLUSIONS}

As originally hypothesized, growth performance of the heifers was maintained when fed DDGS with ad libitum hay compared with being fed a control concentrate mix with ad libitum hay. However, feeding the DDG concentrate mix compared with a CON mix with ad libitum hay did not increase feed efficiency. No differences were observed in BW, ADG, or any of the frame growth variables measured between treatments. A shift in the metabolic profile was demonstrated, but heifers maintained energy status. This demonstrates that producers can limit-feed a DDGS-based concentrate mix with ad libitum grass hay to maintain heifer growth, ADG, and metabolic profile compared with a corn- and soybean-product-based concentrate mix.

\section{ACKNOWLEDGMENTS}

Funding for this research was provided by the South Dakota Agricultural Experiment Station. The authors also thank fellow graduate students and farm personnel in the Dairy Science Department at South Dakota State University, at the time this study was conducted, for their help with sampling and animal care. This research contributes to the goals of the USDA North Central Multi-state Research Project NC-2042: Management Systems to Improve Economic and Environmental Sustainability of Dairy Enterprises.

\section{REFERENCES}

Allain, C. C., L. S. Poon, C. S. G. Chan, W. Richmond, and P. C. Fu. 1974. Enzymatic determination of total serum cholesterol. Clin. Chem. 20:470-475.

Anderson, J. L., K. F. Kalscheur, A. D. Garcia, and D. J. Schingoethe 2015a. Feeding fat from distillers dried grains with solubles to dairy heifers: I. Effects on growth performance and total-tract digestibility of nutrients. J. Dairy Sci. 98:5699-5708.

Anderson, J. L., K. F. Kalscheur, A. D. Garcia, and D. J. Schingoethe. 2015b. Short Communication: Feeding fat from distillers dried grains with solubles to dairy heifers: III. Effects on post-trial reproductive and lactation performance. J. Dairy Sci. 98:5720-5725.

Anderson, J. L., K. F. Kalscheur, A. D. Garcia, D. J. Schingoethe, D. P. Casper, and D. H. Kleinschmit. 2015c. Ensiling characteristics of distillers wet grains with cornstalks and determination of the feeding potential for dairy heifers. Prof. Anim. Sci. 31:359-367.

AOAC International. 1995. Official Methods of Analysis. 16th ed. AOAC International, Arlington, VA.

AOAC International. 2002. Official Methods of Analysis. 17th ed. Association of Official Analytical Chemists, Gaithersburg, MD.

Bach Knudsen, K. E. 1997. Carbohydrate and lignin contents of plant materials used in animal feeding. Anim. Feed Sci. Technol. 67:319 338.

Chaney, A. L., and E. P. Marbach. 1962. Modified reagents for determination of urea and ammonia. Clin. Chem. 8:130-132.

Fahey, G. C., and L. L. Berger. 1988. Carbohydrate nutrition of ruminants. Pages 269-295 in The Ruminant Animal: Digestive Physiology and Nutrition. D. C. Church, ed. Prentice Hall Inc., Upper Saddle River, NJ. 
Fossati, P., and L. Prencipe. 1982. Serum triglycerides determined colorimetrically with an enzyme that produces hydrogen peroxide. Clin. Chem. 28:2077-2080.

Funston, R. N. 2004. Fat supplementation and reproduction in beef females. J. Anim. Sci. 82(E-Suppl.):E154-E161.

Hoffman, P. C. 1997. Optimum body size of Holstein replacement heifers. J. Anim. Sci. 75:836-845.

Hoffman, P. C., C. R. Simson, and M. A. Wattiaux. 2007. Limit-feeding of gravid Holstein heifers: Effect on growth, manure nutrient excretion, and subsequent early lactation performance. J. Dairy Sci. 90:946-954.

Kleinschmit, D. H., J. L. Anderson, D. J. Schingoethe, K. F. Kalscheur, and A. R. Hippen. 2007. Ruminal and intestinal degradability of distillers grains plus solubles varies by source. J. Dairy Sci. 90:2909-2918.

Kutner, M. H., C. J. Nachtsheim, and J. Neter. 2004. Applied Linear Regression Models. 4th ed. McGraw-Hill Companies Inc., New York, NY.

Littell, R. C., G. A. Milliken, W. W. Stroup, R. D. Wolfinger, and O. Schabenberger. 2006. SAS for Mixed Models, 2nd ed. SAS Institute Inc., Cary, NC.

Manthey, A. K., J. L. Anderson, and G. A. Perry. 2016. Feeding distillers dried grains in replacement of forage in limit-fed dairy heifer rations: Effects on growth performance, rumen fermentation, and total-tract digestibility of nutrients. J. Dairy Sci. 99:7206-7215.

Manthey, A. K., J. L. Anderson, G. A. Perry, and D. H. Keisler. 2017. Feeding distillers dried grains in replacement of forage in limit-fed dairy heifer rations: Effects on metabolic profile and onset of puberty. J. Dairy Sci. 100:2591-2602.

Merchen, N. R. 1988. Digestion, Absorption and Excretion in Ruminants. Pages 182-189 in The Ruminant Animal: Digestive Physiology and Nutrition. D. C. Church, ed. Prentice Hall Inc., Upper Saddle River, NJ.

NRC. 2001. Nutrient Requirements of Dairy Cattle. 7th rev. ed. Natl. Acad. Press, Washington, DC.

Park, C. S., G. R. Fisher, and C. N. Haugse. 1980. Effect of dietary protein and sunflower meal on blood serum cholesterol of dairy heifers. J. Dairy Sci. 63:1451-1461.

Park, C. S., W. Rafalowski, and G. D. Marx. 1983. Effect of dietary fat supplement on lipid metabolism on Holstein heifers. J. Dairy Sci. 66:528-534.
Robertson, J. B., and P. J. Van Soest. 1981. The detergent system of analysis and its application to human foods. Pages 123-158 in The Analysis of Dietary Fiber in Food. W. P. T. James and O. Theander, ed. Marcel Dekker Inc., New York, NY.

Schroer, R. C., T. D. Nennich, T. S. Dennis, M. M. Schutz, S. S. Donkin, and D. Little. 2014. Intake and growth of prepubertal dairy heifer fed reduced-fat dried distillers grains. Prof. Anim. Sci. 30:93-98.

Sejrsen, K., J. T. Huber, and H. A. Tucker. 1983. Influence of amount fed on hormone concentrations and their relationship to mammary growth in heifers. J. Dairy Sci. 66:845-855.

Talavera, F., C. S. Park, and G. L. Williams. 1985. Relationships among dietary lipid intake, serum cholesterol, and ovarian function in Holstein heifers. J. Anim. Sci. 60:1045-1051.

Thomas, M. G., B. Bao, and G. L. Williams. 1997. Dietary fats varying in their fatty acid composition differentially influence follicular growth in cows fed isoenergetic diets. J. Anim. Sci. 75:2512-2519.

Trinder, P. 1969. Determination of glucose in blood using glucose oxidase with an alternative oxygen receptor. Ann. Clin. Biochem. 6:24-27.

Van Soest, P. J., J. B. Robertson, and B. A. Lewis. 1991. Methods for dietary fiber, neutral detergent fiber, and non-starch polysaccharides in relation to animal nutrition. J. Dairy Sci. 74:3583-3597.

Wildman, E. E., G. M. Jones, P. E. Wagner, R. L. Boman, H. F. Troutt Jr., and T. N. Lesch. 1982. A dairy cow body condition scoring system and its relationship to selected production characteristics. J. Dairy Sci. 65:495-501.

Zanton, G. I., and A. J. Heinrichs. 2005. Meta-analysis to assess effect of prepubertal average daily gain of Holstein heifers on firstlactation production. J. Dairy Sci. 88:3860-3867.

Zanton, G. I., and A. J. Heinrichs. 2007. The effects of controlled feeding of a high-forage or high-concentrate ration on heifer growth and first-lactation milk production. J. Dairy Sci. 90:3388-3396.

Zanton, G. I., and A. J. Heinrichs. 2008. Rumen digestion and nutritional efficiency of dairy heifers limit-fed a high forage ration to four levels of dry matter intake. J. Dairy Sci. 91:3579-3588.

Zanton, G. I., and A. J. Heinrichs. 2009. Digestion and nitrogen utilization in dairy heifers limit-fed a low or high forage ration at four levels of nitrogen intake. J. Dairy Sci. 92:2078-2094. 